\title{
Fiatalkori iliofemoralis mélyvénás thrombosis ritka oka: tünetmentes vena cava inferior elzáródás
}

\author{
Tóth Gerda Brigitta dr. - Csobay-Novák Csaba dr. \\ Berencsi Anikó dr. - Szeberin Zoltán dr. \\ Semmelweis Egyetem, Általános Orvostudományi Kar, Városmajori Szív- és Érgyógyászati Klinika, \\ Érsebészeti Tanszék, Budapest
}

\begin{abstract}
Bevezetés: A fiatalkori akut mélyvénás thrombosis általában thrombophilia, immobilitás, trauma, mútét, rosszindulatú daganat kapcsán alakul ki, de korábban ismeretlen, krónikus vena cava inferior occlusio is állhat a háttérben. A konzervatív terápia mellett farmakológiai és mechanikus lysiskezelés is választható, ennek indikációjáról és terápiás hasznáról azonban nincs evidencia. Célkitüzés: A szerzők a Semmelweis Egyetem, Városmajori Szív- és Érgyógyászati Klinika, Érsebészeti Tanszéken kezelt betegek adatainak elemzésével a vena cava inferior occlusiójával társult mélyvénás thrombosis kezelési lehetőségeit mutatják be. Módszer: Egy centrumban végzett retrospektív tanulmányban vizsgálták a krónikus vena cava inferior occlusio előfordulási gyakoriságát 2012 és 2014 között. Eredmények: Huszonegy beteg közül négynél igazolták a vena cava inferior krónikus elzáródását vagy nagyfokú szúkületét. A pontos diagnózist adó komputertomográfiás vagy mágneses rezonanciás angiográfia után antikoagulálást kezdtek, katéteres intervenciót nem végeztek. 27,5 \pm 11 hónap követési idő után mindegyik beteg él és panaszmentes. Következtetések: A krónikus vena cava inferior occlusio ritka betegség, proximalis típusú, rekurráló vagy mindkét alsó végtagot érintő mélyvénás thrombosist okozhat. Ezekben az esetekben a farmakomechanikus thrombolysis indikációja kérdéses és a pontos diagnózis felállításához komputertomográfiás vagy mágneses rezonanciás angiográfia is szükséges. Orv. Hetil., 2016, 157(34), 1361-1365.
\end{abstract}

Kulcsszavak: vena cava inferior, mélyvénás thrombosis, thrombolysis, endovascularis technika

\section{A rare cause of ilio-femoral deep vein thrombosis in young adults: asymptomatic chronic inferior vena cava occlusion}

Introduction: Acute lower extremity deep venous thrombosis in young adults is usually related to thrombophilia, immobility, trauma, surgery or malignancy. Therapeutic options have recently included pharmacomechanical thrombus removal although there is no evidence of the indication or of the long-term benefit. Rarely unknown, asymptomatic chronic neonatal inferior vena cava occlusion could also lead to acute ilio-femoral thrombosis. Aim: The aim of the authors was to present the therapeutic possibilities in lower extremity deep venous thrombosis connected with chronic inferior vena cava occlusion. Method: In a retrospective single center study data of 21 adults were analyzed. Results: In 4 of the 21 patients chronic inferior vena cava obstruction was identified as an underlying cause of the acute thrombosis. Pharmacomechanical lysis was not offered to them and anticoagulation therapy was introduced. After an average $27.5 \pm 11$ month follow-up all the patients were alive and no adverse event occurred. Conclusions: In patients with acute lower extremity deep venous thrombosis and chronic inferior vena cava occlusion the indication of the endovenous pharmacomechanical lysis therapy is questionable. The authors suggest to consider computed tomography angiography or magnetic resonance angiography in addition to duplex sonography in patients with no obvious risk factors for lower extremity deep venous thrombosis to avoid unnecessary invasive treatment.

Keywords: inferior vena cava, deep vein thrombosis, thrombolysis, endovascular technique

Tóth, G. B., Csobay-Novák, Cs., Berencsi, A., Szeberin, Z. [A rare cause of ilio-femoral deep vein thrombosis in young adults: asymptomatic chronic inferior vena cava occlusion]. Orv. Hetil., 2016, 157(34), 1361-1365.

(Beérkezett: 2016. május 25.; elfogadva: 2016. június 16.) 


\section{Rövidítések}

MVT = mélyvénás thrombosis; $\mathrm{VCI}=$ vena cava inferior

A vena cava inferior (VCI) hiánya lehet veleszületett vagy szerzett. Agenesiája vagy egyéb fejlődési rendellenessége ritka betegség, a teljes populáció $0,5 \%$-át érinti [1]. A krónikus VCI-occlusio oka lehet veleszületett (embrionális dysgenesis) vagy szerzett (perinatalis vagy intrauterin időszakban elszenvedett vena cava inferior thrombosis) [2]. Utóbbi kapcsolatban lehet újszülöttkori infekciókkal, szepszissel, mellékvesevérzéssel vagy kórházi kezelés kapcsán behelyezett vénás kanüllel. Általában fiatal felnőttkorig tünetmentes, amikor ismeretlen eredetú, repetitív vagy rekurráló, proximalis, esetleg kétoldali mélyvénás thrombosis képében jelenik meg. A kórkép felismerése fontos a kezelés típusának eldöntése szempontjából. Az irodalomban föként esettanulmányok olvashatók a témával kapcsolatban [3-8]. Az alapvetôen konzervatív terápia mellett új típusú farmakológiai, endovascularis és/vagy mechanikus lysiskezelés jelent meg a kezelési lehetőségek között, ennek indikációjáról és esetleg terápiás hasznáról azonban evidencia nem áll rendelkezésre. Tanulmányunk elkészítésének célja beteganyagunk elemzése és eseteink bemutatásán keresztül a VCI occlusiójával társult akut mélyvénás thrombosis (MVT) kezelési lehetőségeinek ismertetése volt.

\section{Módszer}

2012 júniusa és 2014 júniusa között 21 beteget kezeltünk iliofemoralis mélyvénás thrombosissal. Retrospektív, egy centrumban végzett adatgyújtésünk során vizsgáltuk e betegek kórtörténetét (forrás: kórházi adatbázis, személyes vizitek). Természetesen ez a Magyarországon proximalis mélyvénás thrombosis miatt kezelt betegeknek csak egy kisebb hányada, mivel klinikánknak az érsebészeti centrum helyzetéből adódóan csak a speciális, farmakomechanikus lysisre esetleg alkalmas eseteket referálják. A kezelt páciensekből négynél (két férfinál és két nőnél) a proximalis mélyvénás thrombosis okaként krónikus vena cava inferior occlusiót (három esetben) vagy subhepaticus stenosist (egy esetben) azonosítottunk. A tünetek mindegyik betegnél hasonlóak voltak: alsó végtagi oedema, háti, csípőtáji, comb-, illetve lábszárfájdalom.

\section{Eredmények}

A betegek klinikai adatait az 1. táblázatban foglaltuk össze.

A 20 éves nóbetegnél 2011. januárban más intézményben hirtelen kialakuló derékfájdalom és alsó végtagi duzzanat hátterében ultrahang- (UH-) vizsgálat során diagnosztizáltak bal vena iliaca szintü thrombosist. Féléves antikoaguláns terápia után gyógyszeres kezelését leállították, tekintettel a negatív coagulopathiás tesztekre. 2011 decemberében ismételt alsó végtagi duzzanat hátterében a jobb vena iliaca thrombosisa igazolódott. $\mathrm{Az}$ akkor elvégzett UH-vizsgálat felvetette a VCI hiányát. 2012 májusában a VCI agenesiájának vagy krónikus occlusiójának eldöntése céljából elvégzett MR-, majd CT-vizsgálat során észleltük a mindkét iliacarendszert és a VCI infrahepaticus szakaszát érintő krónikus occlusiót, ezzel összefüggésben a kismedencében és a felhasban kialakult gazdag vénás kollaterális hálózatot (1. és 2. ábra). A jobb mellékvesében egy $20 \times 6 \mathrm{~mm}$-es meszesedést is felismertünk, amely a heteroanamnézis alapján egy újszülöttkori szepszis kapcsán kialakult mellékvesevérzés maradványának felel meg, feltehetően ez a kóroki tényező a krónikus VCI-occlusio hátterében $[6,9]$.

A második betegnél a panaszok alapján ( 5 napja észlelt mindkét csípőtáji, alsó végtagokba sugárzó fájdalmak, mérsékelt anasarca) inkább gerinceredetû megbetegedésre gondoltak és ortopédiai kivizsgálást kezdtek. Az

1. táblázat |A klinikánkon krónikus vena cava inferior occlusióval/stenosissal kezelt betegeink tüneteinek, kivizsgálásának és terápiájának összefoglaló táblázata

\begin{tabular}{lllll}
\hline & l. beteg & 2. beteg & 3. beteg & 4. beteg \\
\hline Életkor (év) & 20 & 14 & 28 & 47 \\
\hline Nem & Nó & Férfi & Nón & Férfi \\
\hline Anamnézis & $\begin{array}{l}\text { Csecsemókori } \\
\text { mellékvesevérzés }\end{array}$ & Negatív & $\begin{array}{l}\text { Femoralis vénakanül } \\
\text { csecsemókorban }\end{array}$ & Negatív \\
\hline Tünetek & $\begin{array}{l}\text { Végtagoedema, } \\
\text { hátfájdalom }\end{array}$ & Végtagfájdalom & Alhasi, deréktáji fájdalom & Végtagoedema, fájdalom \\
\hline Thrombophiliavizsgálat & Negatív & Nem készült & Negatív & Negatív \\
\hline Képalkotó vizsgálat & UH, CT, MR & CT, MR & UH, MR & UH, CT \\
\hline Terápia & $\begin{array}{l}\text { Acenokumarol } \\
\text { tartósan }\end{array}$ & $\begin{array}{l}\text { Acenokumarol } \\
\text { l év }\end{array}$ & $\begin{array}{l}\text { Acenokumarol } \\
\text { 6 hónap }\end{array}$ & $\begin{array}{l}\text { Warfarin } \\
\text { tartósan }\end{array}$ \\
\hline Státusz (CEAP) & C²sEsAdPo & CªEsAdPo & CªEsAdPo & CªEsAdPo \\
\hline
\end{tabular}

$\mathrm{CEAP}=\mathrm{A}$ krónikus alsó végtagi vénás betegségek osztályozására létrehozott rendszer, amelyben a klinikai tünetek (clinical), etiológia (etiology), anatómia (anatomy) és patofiziológia (pathophysiology) alapján történik a besorolás. 


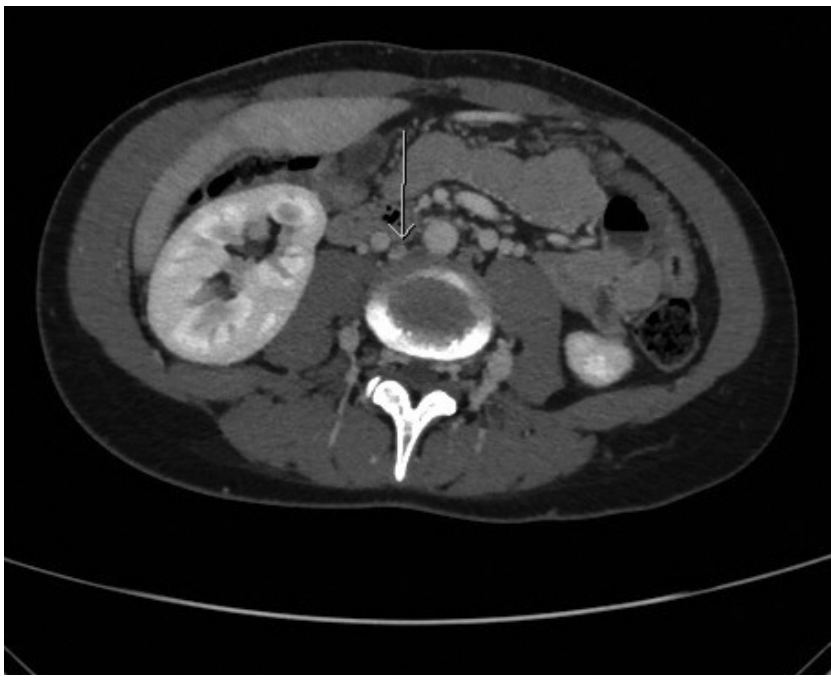

1. ábra

Az l. beteg axiális CTA-képe, amelyen a nyíl jelöli a krónikusan occludált vena cava inferiort

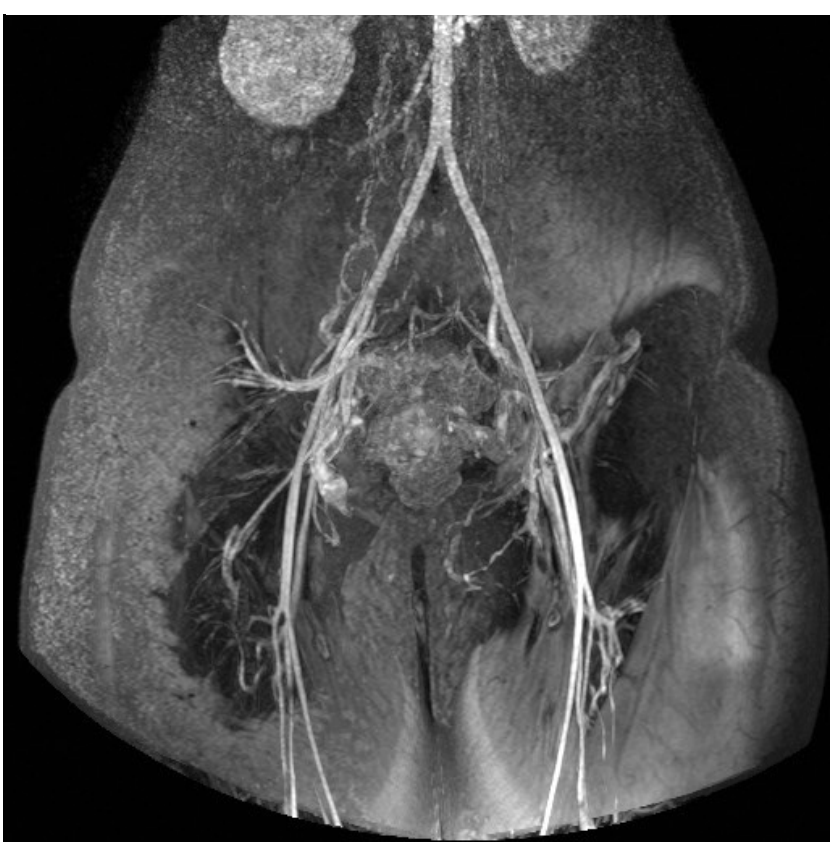

2. ábra Az l. beteg coronalis síkú MR-felvétele, amelyen látható a vena
cava inferior környezetében a kiterjedt vénás kollaterális hálózat

elvégzett MR-vizsgálat már felvetette a VCI és a vena iliacák occlusióját (3. ábra), ám az L.II.-S.II. csigolyák magasságában látott kontrasztanyag-halmozás az epiduralis térben, illetve a betegnél megjelenő egynapos láz infektológiai irányba terelte a kezelőorvosok figyelmét. A panaszok perzisztálása miatt elvégzett CT-vizsgálat igazolta a subhepaticus VCI krónikus occlusióját és mindkét vena iliaca communis, interna és externa akut thrombosisát, kiterjedt vénás kollateralizációval. A lumbosacralis szakaszon észlelt kontrasztanyag-halmozás a kiterjedt vénás kollateralizációnak felel meg.

A harmadik betegnél alhasi, deréktáji fájdalmak miatt végzett kivizsgálás (UH-, majd MRA-vizsgálat) során

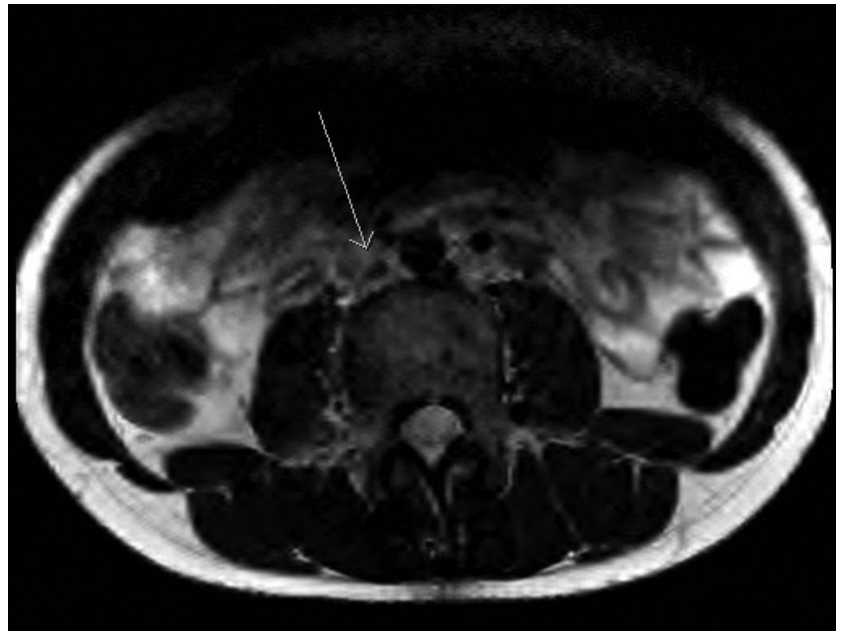

3. ábra

A 2. beteg MR-képe. A nyíl a krónikus vena cava inferior occlusióra mutat

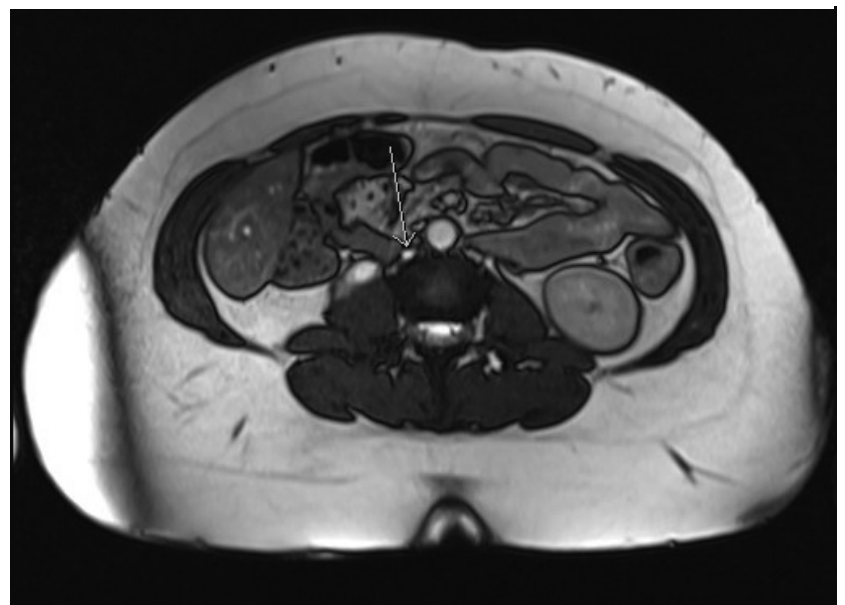

4. ábra A 3. beteg MR-felvétele, amelyen könnyen azonosítható az occludált VCI

derült fény az infrarenalis VCI, a jobb vena iliaca communis, interna és externa krónikus occlusiójára és a kompenzatorikusan kialakult tágabb jobb parametrialis vénás plexusra (4. és 5. ábra). A más intézményben elvégzett thrombophiliatesztek negatívnak bizonyultak. A szülőktől felvett heteroanamnézis alapján kórokként sikerült azonosítani a csecsemókorban, kamrai septumdefektus mútéti megoldása kapcsán a jobb femoralis vénába behelyezett kanült.

A negyedik betegnek sem perinatalisan, sem később komolyabb megbetegedése nem volt. Hirtelen kezdődő, mindkét alsó végtagra kiterjedő, combtőig tartó duzzanat és fájdalom miatt került belgyógyászati felvételre. Az elvégzett UH-vizsgálat kétoldali iliofemoralis thrombosist igazolt. Az UH-vizsgálat során észlelt meglassult keringés hátterében a CT-vizsgálat igazolta a VCI intrahepaticus szakaszának nagyfokú krónikus szúkületét, mindkét vena iliaca communis, a subhepaticus VCI és a jobb vena renalis akut thrombosisát, illetve a bal renalis véna krónikus occlusióját, gazdag perirenalis kollaterális 


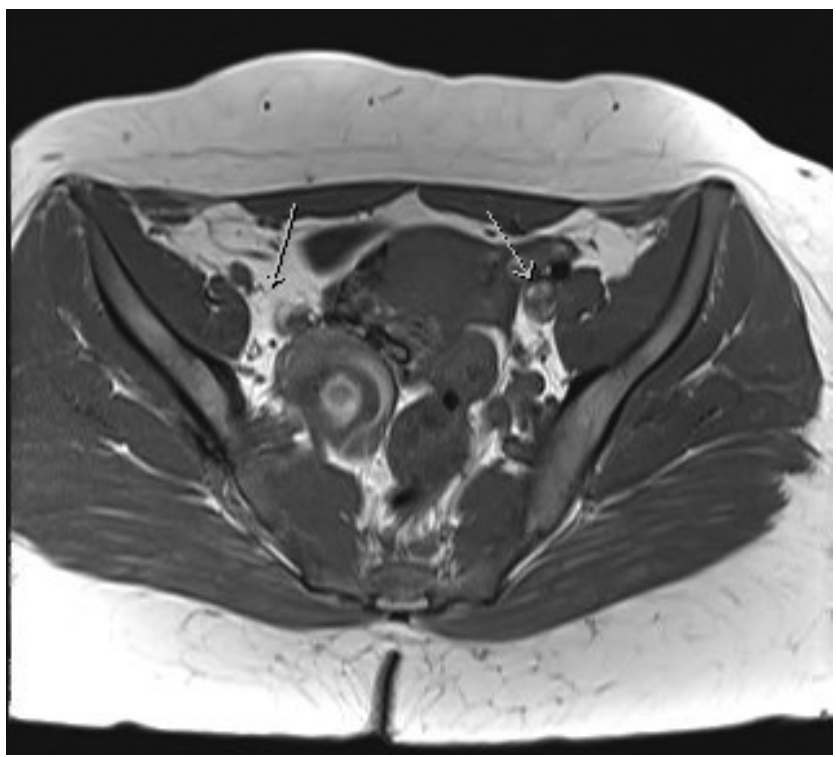

5. ábra

MR-felvétel a 3. betegról, amelyen a jobb vena iliaca communis occlusioja és a bal vena iliaca communis thrombosisa látszódik a nyíllal jelölt helyeken

hálózattal (6. ábra). A később elvégzett thrombophiliavizsgálat ebben az esetben is negatívnak bizonyult.

Hajlamosító tényezők (immobilitás, trauma, műtét, terhesség, rosszindulatú daganat, antikoncipiens szedése) egyik betegnél sem voltak fellelhetők. A diagnózis felállítása után betegeinknél nem végeztünk rekanalizációt, hanem kezelésükben az alsó végtagi kompressziós terápia mellett az orális antikoaguláns (terápiás LMWH, majd három esetben acenokumarol, egy esetben warfarin) gyógyszereket részesítettük előnyben.

Betegeink átlagosan 27,5 \pm 11 (átlag \pm szórás) hónapos követése során ismételt mélyvénás thrombosis nem

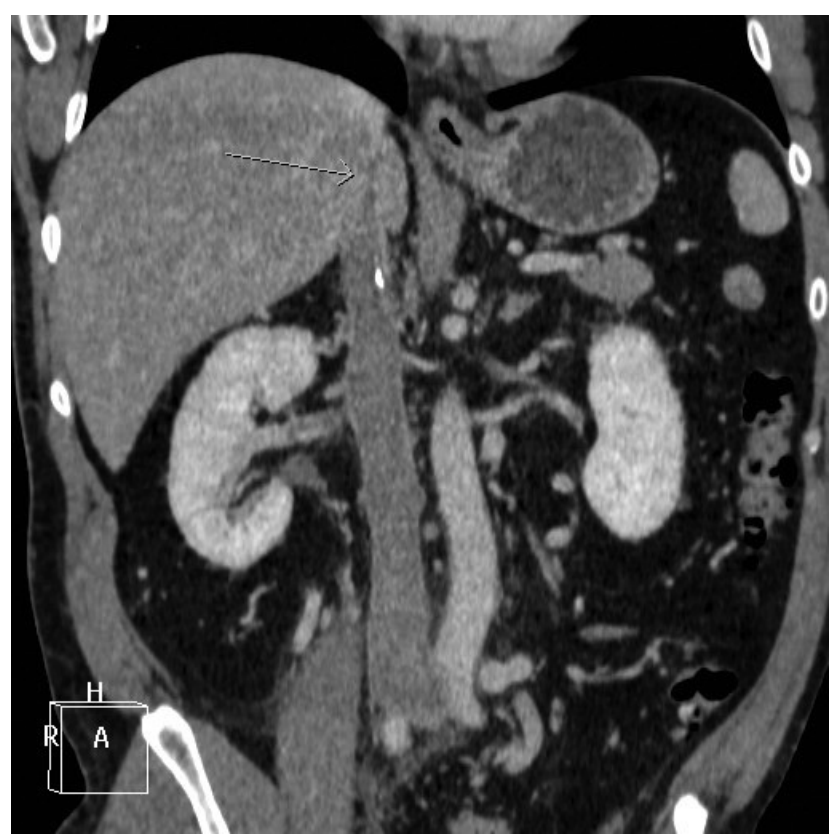

6. ábra

A 4. beteg coronalis síkú CTA-felvétele, az intrahepaticus VCI stenosissal (nyíl) jelentkezett. Három betegnél észleltünk tünetmentes reticularis varicositast az alsó végtagokon, egy betegnél az elváltozás érintette a hasfalat is. Két betegnél jelentkezett mérsékelt alsó végtagi oedema. Egy beteg teljesen tünet- és panaszmentes. A megkezdett antikoaguláns terápiát két betegnél 6 , illetve 12 hónap után felfüggesztettük. A további két páciens jelenleg is antikoaguláns kezelés alatt áll.

\section{Megbeszélés}

Intézetünkben a VCI occlusiójával járó esetekben a konzervatív terápiát részesítjük előnyben, bár az irodalomban néhány esetben jó eredményt értek el farmakomechanikus lysissel $[10,11]$. Garg és mtsai munkájában egy Leiden-heterozigóta, VCI-agenesiában szenvedő betegnél történt mindkét iliaca communist érintő akut thrombosisban farmakomechanikus lysis. A kiváltó ok megszüntetése nem történt meg, és a beteg élethosszig tartó antikoaguláns terápiára szorul [10]. Haskal és mtsai publikációjában egy Budd-Chiari-szindrómás betegnél történt endovascularis rekanalizáció, „neocava” képzés thrombolysis mellett [11]. Bár mind a két beteg tünetmentesnek bizonyult az utánkövetés alatt, de ez a második betegnél mindösszesen 12 hetet jelentett.

A jelenlegi irányelvek alapján akut alsó végtagi mélyvénás thrombosis esetén választandó terápia az azonnali új típusú orális antikoaguláns gyógyszerek bevezetése (bizonyos fajtáknál iniciális parenteralis LMWH adása után). Egyes betegcsoportokban (tumoros betegek) megmaradt a hagyományos, hosszú távú LMWH-terápia. A kezelés időtartama függ a kiváltó októl, a folyamat kiterjedésétől és a háttérben álló kórállapotoktól [12, $13]$.

Az invazív kezelések között a korábbi sebészeti megoldások, illetve a szisztémás lysis hosszú távú sikertelensége után jelentek meg az új endovascularis technikák. A farmakomechanikus lysis és endovascularis rekanalizáció eredményei az akut, szubakut és néhány esetben a krónikus iliofemoralis-poplitealis mélyvénás thrombosis esetén biztatóak, de a jelenleg érvényes ajánlások megváltoztatásához további randomizált vizsgálatokra van szükség [14-16].

$\mathrm{Az}$ akut iliofemoralis mélyvénás thrombosis mellett meglévő VCI krónikus occlusio diagnózisa nehéz. A kivizsgálás során az anamnézis részletes felvétele alapvető fontosságú. Figyelembe kell venni a halmozott vagy repetitív proximalis típusú, masszív mélyvénás thrombosisok jelenlétét, a provokáló tényezők meglétét vagy hiányát, a rutinszerúen végzett thrombophiliatesztek eredményét. Ezek függvényében szükséges lehet CTA vagy - a betegek fiatal korát mérlegelve - MRA-vizsgálat is, amely pontos képet ad a VCI státuszáról. Az elsóként választandó terápia jelenleg az alsó végtagi kompressziós kezelés mellett az (esetlegesen teljes életen át tartó) antikoagulálás. $\mathrm{Az}$ endovascularis eljárások, mint farmakomechanikus thrombolysis és VCI-rekanalizáció hosszú 
távú hatékonyságára jelenleg nincs egyértelmú bizonyíték [17].

Eseteinkben és az irodalmi tapasztalok alapján az endovénás, farmakomechanikus thrombolysis indikációja kérdéses krónikus VCI-elzáródás esetén. Azoknál a betegeknél, akiknél nincsenek jelen a masszív, proximalis típusú vagy kétoldali mélyvénás thrombosis nyilvánvaló rizikótényezói, a pontos diagnózishoz a duplex ultrahangvizsgálaton kívül CT- vagy MR-angiográfiás vizsgálat is indokolt a nem bizonyítottan hatásos, költséges és szövődményveszélyt jelentő invazív beavatkozás elkerülése céljából.

Anyagi támogatás: A közlemény megírása és az ahhoz kapcsolódó kutatómunka anyagi támogatásban nem részesült.

Szerzôi munkamegosztás: T. G. B.: A vizsgálat lefolytatása, a kézirat megírása és a betegek utánkövetése. Cs.-N. Cs.: A képalkotó vizsgálatok értékelése, a képek kiválasztása és részvétel a kézirat szerkesztésében. B. A.: A betegek utánkövetése, a táblázat szerkesztése. Sz. Z.: A hipotézis felállítása, a kézirat javítása. A cikk végleges változatát valamennyi szerző elolvasta és jóváhagyta.

Érdekeltségek: A szerzőknek nincsenek érdekeltségeik.

\section{Irodalom}

[1] Sitwala, P. S., Ladia, V. M., Brabmbhatt, P. B., et al.: Inferior vena cava anomaly: a risk for deep vein thrombosis. North Am. J. Med. Sci., 2014, 6(11), 601-603.

[2] Lambert, M., Marboeuf, P., Midulla, M., et al.: Inferior vena cava agenesis and deep vein thrombosis: 10 patients and review of the literature. Vasc. Med., 2010, 15(6), 451-459.

[3] Devooghdt, M., Favoreel, N., van Holsbeeck, B., et al.: Agenesis of the infrarenal inferior vena cava. J. Belgian Soc. Radiology, 2013, $96(2), 94$.

[4] Hooda, D., Penumetsa, K., Jackson, T., et al.: Congenital absence of inferior vena cava with idiopathic deep vein thrombosis in an adult. West Virginia Med. J., 2013, 109(2), 28-30.

[5] Kraft, C., Hecking, C., Schwonberg, J., et al.: Patients with inferior vena cava thrombosis frequently present with lower back pain and bilateral lower-extremity deep vein thrombosis. VASA, 2013, 42(4), 275-283.

[6] Lavens, M., Moors, B., Thomis, S.: Deep venous thrombosis in a young woman with hypoplastic inferior vena cava. Ann. Vasc. Surg., 2014, 28(4), 1036.e5-1036.e7.

[7] Paddock, M., Robson, N.: The curious case of the disappearing IVC: a case report and review of the aetiology of inferior vena cava agenesis. J. Radiol. Case Rep., 2014, 8(4), 38-47.

[8] Patel, V. K., Warner, B., Ceccherini, A., et al.: An unusual cause of bilateral deep vein thrombosis in a young adult patient. Acute Med., 2011, 10(1), 29-31.

[9] Errington, M. L., Hendry, G. M.: The rare association of right adrenal haemorrhage and renal vein thrombosis diagnosed with duplex ultrasound. Pediatr. Radiol., 1995, 25(2), 157-158.

[10] Garg, K., Cayne, N., Jacobowitz, G.: Mechanical and pharmacologic catheter-directed thrombolysis treatment of severe, symptomatic, bilateral deep vein thrombosis with congenital absence of the inferior vena cava. J. Vasc. Surg., 2011, 53(6), 1707-1710.

[11] Haskal, Z. J., Potosky, D. R., Twaddell, W. S.: Percutaneous endovascular creation of an inferior vena cava in a patient with caval agenesis, Budd-Chiari syndrome, and iliofemorocaval thrombosis. J. Vasc. Interv. Radiol., 2014, 25(1), 63-69.

[12] Kearon, C., Akl, E. A., Ornelas, J., et al.: Antithrombotic therapy for VTE disease: CHEST guideline and expert panel report. Chest, 2016, 149(2), 315-352.

[13] Toth, P. P.: Considerations for long-term anticoagulant therapy in patients with venous thromboembolism in the novel oral anticoagulant era. Vasc. Health Risk Manag., 2016, 12, 23-34.

[14] Finks, S. W., Trujillo, T. C., Dobesh, P. P.: Management of venous thromboembolism: recent advances in oral anticoagulation therapy. Ann. Pharmacother., 2016, 50(6), 486-501.

[15] Köksoy, C., Yilmaz, M. F., Başbuğ, H. S., et al.: Pharmacomechanical thrombolysis of symptomatic acute and subacute deep vein thrombosis with a rotational thrombectomy device. J. Vasc. Interv. Radiol., 2014, 25(12), 1895-1900.

[16] Stanley, G. A., Murphy, E. H., Plummer, M. M., et al.: Midterm results of percutaneous endovascular treatment for acute and chronic deep venous thrombosis. J. Vasc. Surg. Venous Lymphat. Dis., 2013, $1(1), 52-58$.

[17] Casey, E. T., Murad, M. H., Zumaeta-Garcia, M., et al.: Treatment of acute iliofemoral deep vein thrombosis. J. Vasc. Surg. $2012,55(5), 1463-1473$.

(Tóth Gerda Brigitta dr., Budapest, Városmajor utca 68., 1122 e-mail: gerda.toth.md@gmail.com) 